\title{
Fish kills, bottom-water hypoxia, and the toxic Pfiesteria complex in the Neuse River and Estuary
}

\author{
JoAnn M. Burkholder ${ }^{1, *}$, Michael A. Mallin ${ }^{2}$, Howard B. Glasgow $\mathrm{Jr}^{1}$ \\ 'Department of Botany, Box 7612, North Carolina State University, Raleigh, North Carolina 27695, USA \\ ${ }^{2}$ Center for Marine Science Research, The University of North Carolina at Wilmington, 7205 Wrightsville Ave., Wilmington, \\ North Carolina 28403, USA
}

A recent paper by Paerl et al. 'Ecosystem responses to internal and watershed organic matter loading: consequences for hypoxia in the eutrophying Neuse River Estuary, North Carolina, USA' (1998; Mar Ecol Prog Ser 166:17-25) makes the statement that increased nitrogen loading to the Neuse River Estuary has led to algal blooms which produced organic matter loads capable of causing extensive hypoxic and anoxic conditions that, in turn, have induced widespread mortality of resident fin- and shellfish (p 17). In this Comment we demonstrate that Paerl et al.'s central conclusion about finfish kills is not supported either by their data or by any statistical analysis, despite invoking predictability ('Results and discussion', p 20-24, Paerl et al. 1998). The paper contains numerous misinterpretations and misuse of literature citations. Paerl et al. also made serious errors of omission, germane from the perspective of science ethics, in failing to cite peerreviewed, published information that attributed other causality to various fish kills that they described.

When attempting to make the difficult step from correlation to implication of causality in a field setting, the available evidence for multiple causative factors should be considered - especially when dealing with a topic that has significant implications for policy makers, scientists, and the general public. Accordingly, formal correction of the Paerl et al. paper is necessary because of the authors' (1) lack of depth profiles of dissolved oxygen (DO) data to support any of their conclusions about kills of surface-schooling fish, (2) use of unrecorded or nonexistent fish kill data, as well as misconveyance of fish kills as reported in the State database upon which they relied, (3) apparent lack of

•E-mail: joann_burkholder@ncsu.edu understanding about the behavior of resident fish populations, (4) misuse of literature citations, (5) omission of a large body of peer-reviewed, published information on the same fish kills (1995-1996), and (6) lack of any supporting statistical analyses to demonstrate relationships among field dissolved oxygen, nutrient, and fish kill data.

Lack of supporting dissolved oxygen/fish kill data and literature. The only DO data that Paerl et al. presented were from the bottom water. A much more complete database (laboratory of J.M.B. \& H.B.G.; summary reports covering the period 1993 through 1996 , available from the Division of Water Quality [DWQ] of the North Carolina Department of Environment \& Natural Resources [NC DENR]) than that discussed by Paerl et al. contains information for physical, chemical, and biological factors on the mesohaline Neuse. This area (Fig. 1) includes the segments addressed in Paerl et al. and the segments where major fish kills historically have occurred in that estuary. Here we compare Paerl et al.'s contentions, based on biweekly data from 6 to 8 mainstem Neuse stations, with the data of our State-certified laboratory, including DO depth profiles. We report weekly data from 6 stations in the mainstem, mesohaline Neuse (Flanners Beach/Kennel Beach to Minnesott/Cherry Point), as well as data from freshwater segments following a major storm in late summer 1996. These data show that in summers of averageprecipitation years without hurricanes, hypoxic waters in the Neuse Estuary generally were constrained to the bottom third of the water column (Figs. 2 to 4 of this paper; hypoxia considered as in Paerl et al.).

Paerl et al. stated that they used a fish kill database from NC DWQ (formerly the Division of Environmental Management [DEM] of the NC Department of Environment, Health \& Natural Resources [NC DEHNR]) as 


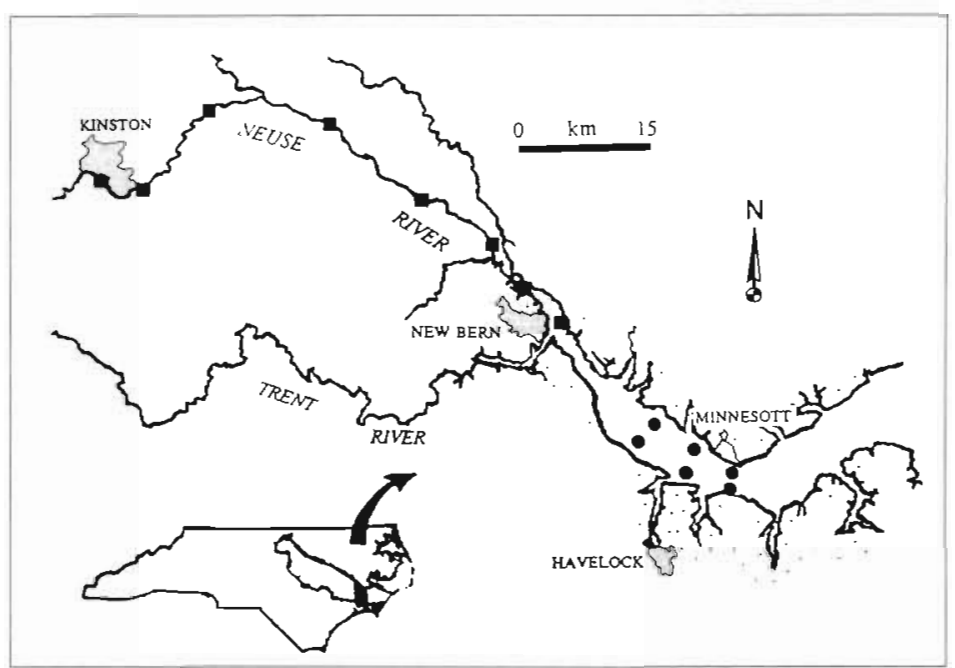

Fig. 1. Study area (estuary indicated by the blackened area within the Neuse watershed, outlined in the North Carolina map inset) showing 6 stations ( $)$ in the mainstem Neuse Estuary. Stations near the north shore were $750 \mathrm{~m}$ out from Kennel Beach, the mouth of Beards Creek, and Minnesott; stations near the south shore were $750 \mathrm{~m}$ out from Flanner Beach, the mouth of Slocum Creek, and Cherry Point. The 8 additional stations ( $\square$ ) that were sampled in September-October 1996 following Hurricane Fran included (1) Kinston (Highway 70 bridge, ca $10 \mathrm{~km}$ upstream from the municipal wastewater treatment plant that was inoperable for several weeks following the hurricane, (2) the Highway 55 bridge at Albrittons Landing, ca $10 \mathrm{~km}$ downstream from the municipal wastewater treatment plant, (3) Bectons Old Field Landing, (4) Cox Landing, (5) Maple Cypress Road Bridge, (6) Redhill Landing, (7) Streets Ferry, and (8) the Highway 17 bridge near Union Point at New Bern. Municipal boundaries (Kinston, New

Bern, Havelock, Minnesott) are shown in grey their sole source of fish kill information. The addage that the absence of evidence does not constitute evidence of absence is sometimes germane when considering the monitoring of fish kills by some State agencies; indeed, Lowe et al. (1991) evaluated North Carolina's State fish kill records (from the 1980s) as the worst among the southeastern states (improvements in the database have been imposed since 1997). However, Paerl et al. cited only NC DWQ (NC DEM) fish kill data as the basis for their writing. One small fish kill was listed for 1994 (12 July) in the State database. Atlantic menhaden Brevoortia tyrannus Latrobe were described in that State record as having been dead for 24 to $36 \mathrm{~h}$ by the time the kill was evaluated, and the record listed the cause of the kill as unknown since DO apparently was at acceptable levels ( $>5 \mathrm{mg} \mathrm{l}^{-1}$; NC DEHNR 1996a). Paerl et al., however, noted that 'A few small fish kills ( $<500$ fish killed per event) occurred in this region during the hypoxic period.' ( $p$ 21). There is no indication of the source of those fish kill data-we have re-confirmed with NC DWQ personnel that no such data were available from the source given by Paerl et al.

Beyond use of fish kill data that do not exist in the State records, upon which Pearl et al. relied, a second major problem in Paerl et al.'s paper regarding 1994 is shown by actual DO depth profile data. Paerl et al. invoke bottom-water hypoxia as the sole causative factor for fish kills in

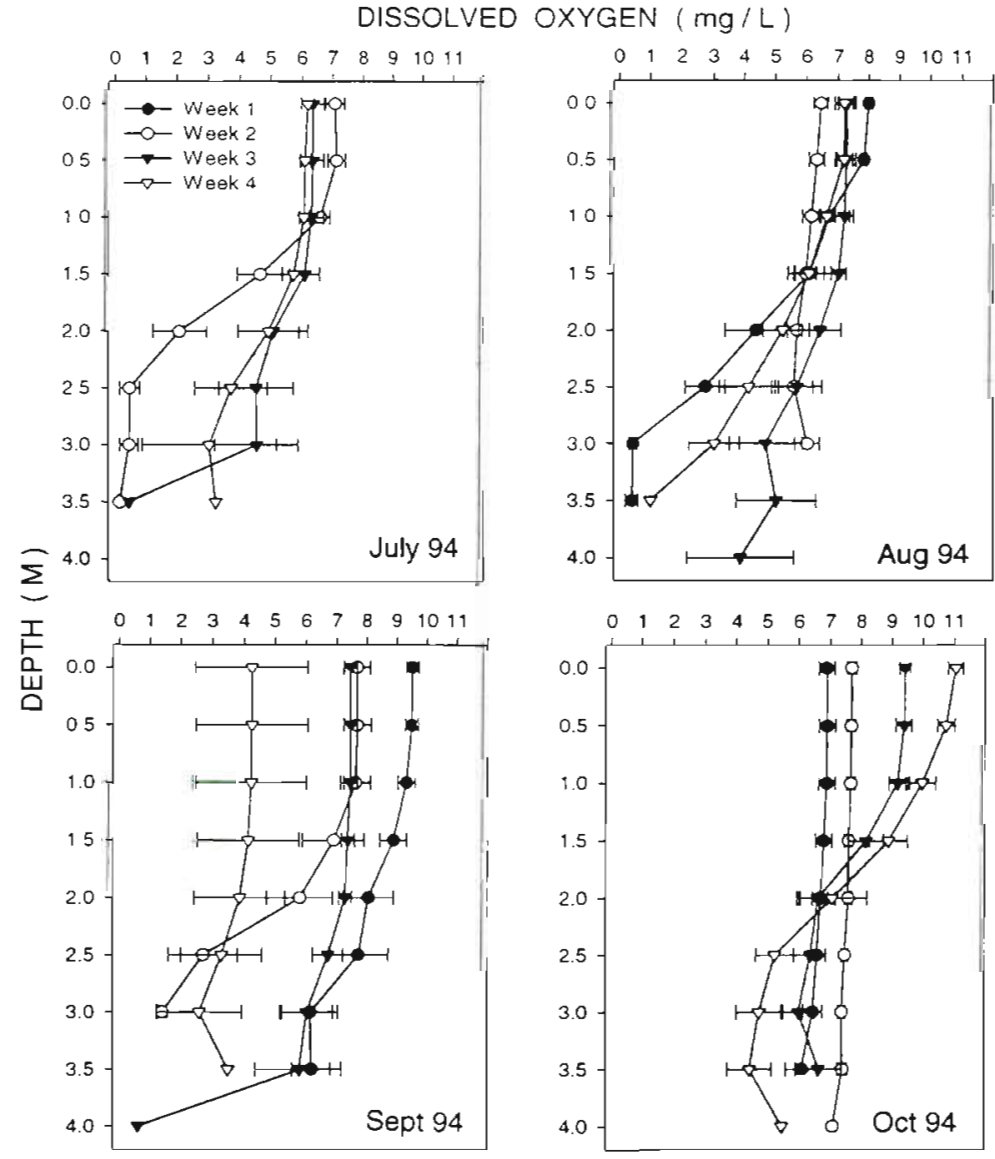

Fig. 2. Depth profiles (mean $\pm 1 \mathrm{SE}$ ) of dissolved oxygen (DO) in 1994 at the 6 stations in the mesohaline Neuse Estuary during the summer-early auturnn period, when fish kills typically occur in the estuary (profiles were taken weekly except in July, when sampling occurred on only 3 dates). Note that fish kills were not reported in this year, despite the fact that low DO occurred in more than one third of the water column during Week 2 in July, in the lower 0.5 to $1.0 \mathrm{~m}$. for 1 to $2 \mathrm{wk}$ in both August and September, and throughout the water column at some stations during Week 4 of September 


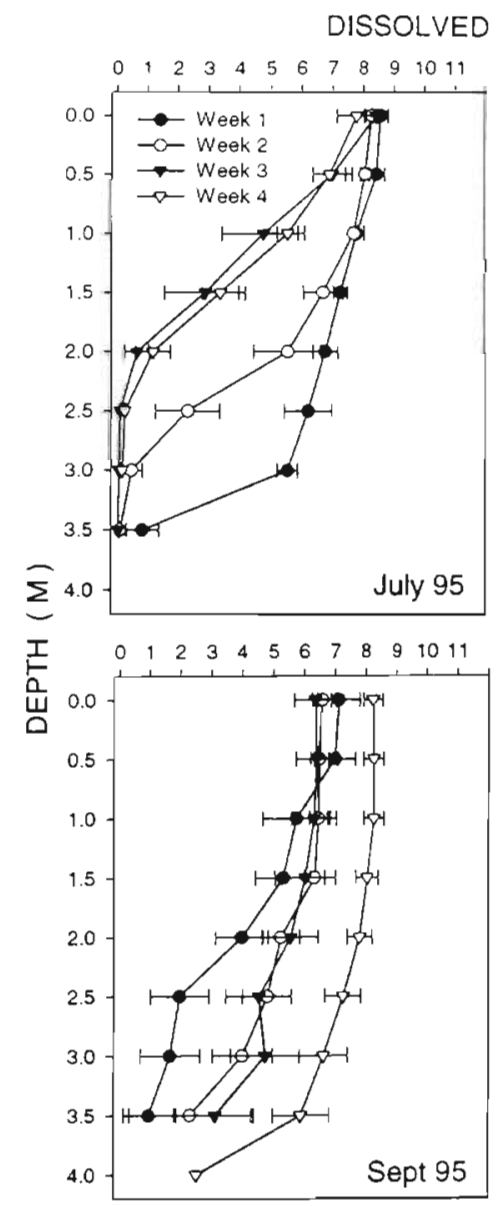

OXYGEN ( $\mathrm{mg} / \mathrm{L})$
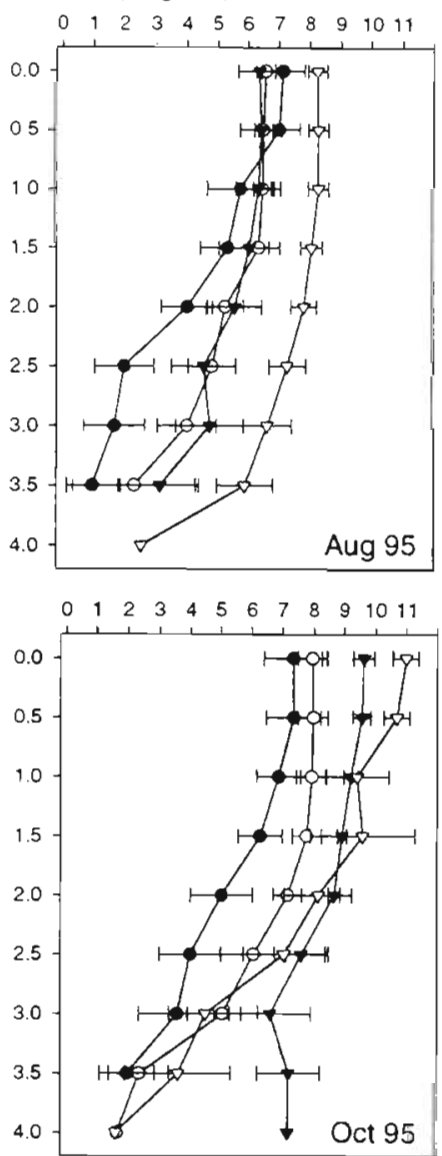

Fig. 3. Depth profiles (mean \pm 1 SE) of DO concentrations in 1995 at the 6 stations in the mesohaline Neuse Estuary during summer-early autumn 1995. A fish kill lasting $5 \mathrm{~d}$ was attributed to low DO during Week 3 of July, and coincided with hypoxia extending to $1.0 \mathrm{~m}$ at the affected station (also see Burkholder \& Glasgow 1997). During the period from Week 4 of September to Week 3 of October, a major fish kill affected ca 14 million surface-dwelling Atlantic menhaden. Approximately $95 \%$ of these fish died with open bleeding lesions while toxic Pfiesteria piscicida was present at densities known to be lethal to fish (800 to 1100 cells $\mathrm{m} \mathrm{l}^{-1}$; Burkholder \& Glasgow 1997). Note that DO was greater than $5 \mathrm{mg} \mathrm{l}^{-1}$ in the upper ca two-thirds of the water column during most of this major fish kill and throughout the kill there was no evidence for any low DO water near the surface in the area where the fish schooled and died

haden (juveniles, as stated in Burkholder \& Glasgow 1997). Atlantic menhaden are surface-dwelling fish (Manooch 1988, Migdalski \& Fichter 1989, Vaughn 1991, Hettler \& Barker 1993), and their abundance has been directly correlated with phytoplankton densities in the field (Friedland et al. 1989). For Paerl et al.'s contention to hold, these menhaden would have had to leave the welloxygenated, plankton-rich upper two-thirds of the water column, descend to the lower third of the water column, and remain there in an oxygen-poor environment until they died or became seriously impaired. Previous studies indicate that finfish and shrimp avoid areas where DO is less than $2 \mathrm{mg} \mathrm{l}^{-1}$ if more oxygen-replete habitat is available (e.g. Renaud 1986, Pihl et al. 1991, Breitburg 1994). Nine of the ten 1995 Neuse fish kills listed by NC DWQ occurred in open estuarine waters rather than enclosed creeks and covered an average segment length of 9 river $\mathrm{km}$ where oxygen was plentiful in the upper water column except from mid- to late July (Fig. 3). Thus, in most of these kills, inability to avoid oxygen-poor bottom water would not have been a problem. Even so, we note that a fish kill in the mainstem Neuse Estuary which was recorded by the State and by our laboratory during the period from mid- to late July 1995 was attributed to low oxygen as a likely causative factor (first fish kill of 1995 reported for the Neuse, with hypoxia/anoxia in half to two-thirds of the water column; Burkholder \& Glasgow 1997).

Paerl et al. claimed that the major fish kill of September-October 1995 was caused by bottom-water hypoxia and anoxia. Paerl et al.'s Figs. 1 \& 4 indicate that the extent of bottom-water hypoxia/anoxia in JulyAugust 1994 and 1996 was comparable to that in July-August 1995 (when some fish kills occurred), yet no fish kills were

the Neuse Estuary. During 1994, hypoxia and anoxia (<4 $\mathrm{mg} \mathrm{DO}^{-1}$ and negligible $\mathrm{DO} \mathrm{l}^{-1}$, respectively; $\mathrm{NC}$ DENR DWQ) affected more than a third of the water column on some dates, actually extending through ca half of the water column during mid-July, early and late August, and late September (Fig. 2), yet there were no fish kills except for the small event of 'unknown cause' that was recorded in the State record on 12 July.

The NC DWQ fish kill database indicated that fish kills in the Neuse Estuary during summer and fall 1995 were wholly or largely comprised of Atlantic men- recorded in the hypoxic/anoxic areas by NC DWQ in 1994 (exception: the 12 July kill, which the State record did not attribute to low DO) or pre-Hurricane Fran in 1996. Nor did Paerl et al. note any major fish kills prior to Hurricane Fran. An intrusion that drives anoxic waters to the shallows along a stretch of shoreline may cause benthic fish kills in some aquatic ecosystems (Breitburg 1992), but Paerl et al. showed no data tracking low-DO water from the bottom depths to demonstrate that any of the Neuse Estuary kills of surface-schooling menhaden were caused, or influenced, by such a phenomenon. During intensive monitoring, 

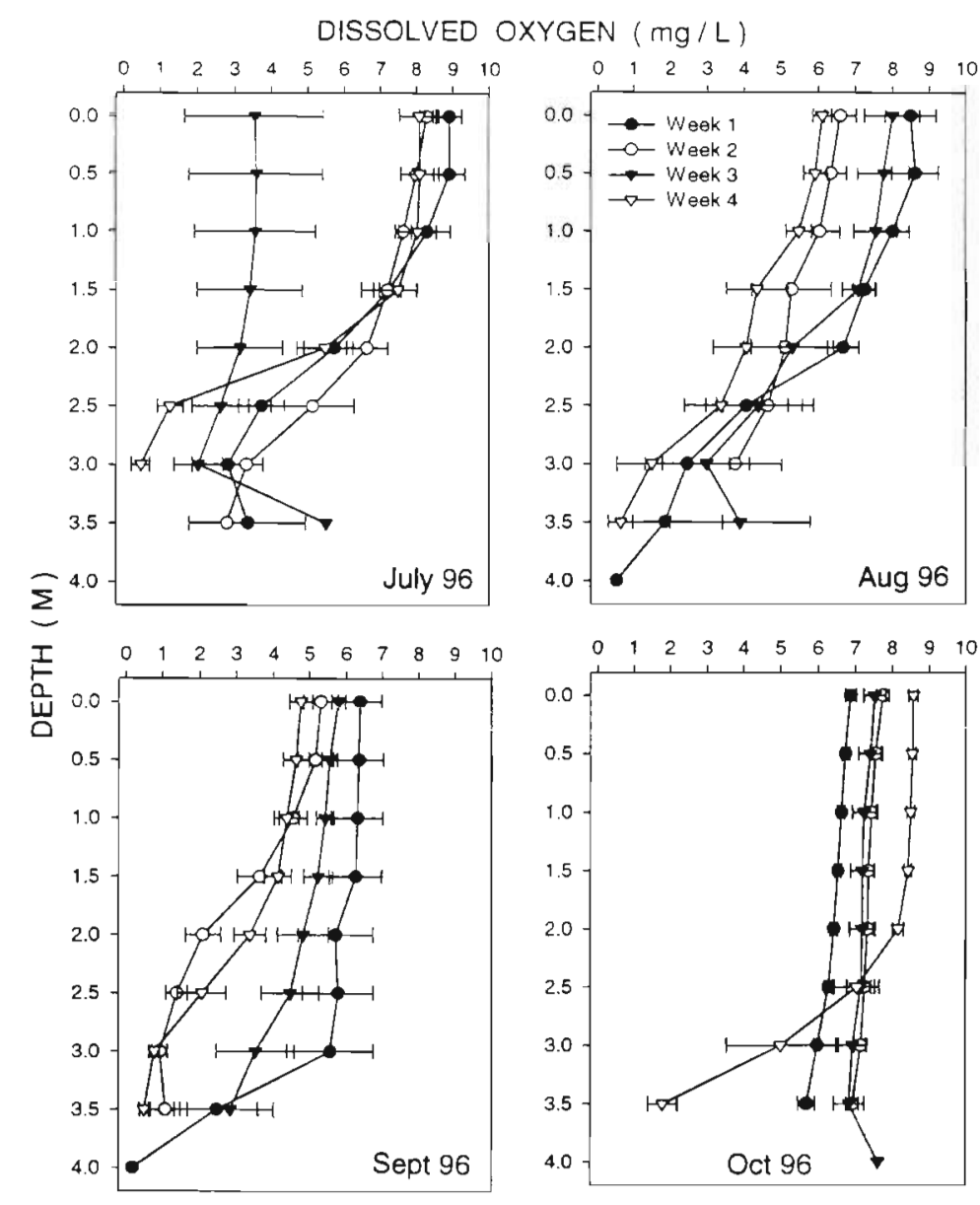

Fig. 4. Depth profiles (mean \pm SE) of DO concentrations (in 1996) at the 6 stations in the mesohaline Neuse Estuary during summer-early autumn 1996. One small kill of Atlantic menhaden (several thousand fish affected) occurred in mid-July when DO was $>5 \mathrm{mg} \mathrm{I}^{-1}$ except in the lower third of the water column (Burkholder \& Glasgow 1997). Kills did not occur at stations with hypoxia throughout the water column (Week 3 , July), likely because of the availability of large adjacent refuge areas of waters with DO $>4 \mathrm{mg} \mathrm{l}^{-1}$ Note that Weeks 1 through 4 of September correspond, respectively, to 2 d prior to Hurricane Fran (Week 1) and 6, 20 , and $27 \mathrm{~d}$ following the hurricane. During Week 2 of September, following Hurricane Fran, over wide areas DO was at 4.0 to $5.5 \mathrm{mg} \mathrm{l}^{-1}$ in the upper $1 \mathrm{~m}$ of the water column, then declined below $4 \mathrm{mg}^{-1}$ over about half of the water column. Nonetheless, there were no records of fish kills in the mesohaline Neuse Estuary throughout the post-hurricane sampling period from Week 2 in September through October

we did not record any evidence of intrusions in or near any of the kills that we have attributed to factors other than hypoxia (Burkholder \& Glasgow 1997). Lacking evidence for such intrusion events, during the September-October 1995 fish kill, finfish likely encountered reduction of usable habitat from bottom-water hypoxia (e.g. Pihl et al. 1991, Diaz et al. 1992). But there is no evidence from Paerl et al. or elsewhere that finfish such as Atlantic menhaden would die from hypoxia when oxygen was plentiful in the upper water column or in adjacent refuge waters.
In contrast with 1994-1995, during late summer 1996 category 3 Hurricane Fran caused loading of millions of liters of raw sewage, swine industry wastes, and swamp waters into the Neuse and other major river systems in the North Carolina (NC DEHNR 1996b, Mallin et al. 1999). Total water-column anoxia/hypoxia in freshwater segments of the Neuse (Figs. 1 \& 5) coincided with major fish kills - a completely different situation than in the previous $2 \mathrm{yr}$. During 1996, the linkage between (complete) water-column anoxia/hypoxia and fish kills was clear (Bales et al. 1996. Anonymous 1997; Fig. 5). The oligohaline estuary generally extends downstream from New Bern (e.g. Paerl et al. 1995, NC DWQ records). Following Hurricane Fran, salt- waters were pushed much farther downstream than usual (NC DWQ database; also summary reports to NC DWQ from laboratory of J.M.B. \& H.B.G.). Shortly after the hurricane in the normally oligohaline area of the Neuse near New Bern, during field sampling efforts, we observed well over a milLion dead fish floating or entangled in shoreline vegetation (Burkholder \& Glasgow 1997). However, these fish consisted mostly of freshwater species (channel catfish Ictalurus punctatus Rafinesque, bluegill Lepomis macrochirus Rafinesque and redbreast sunfish Lepomis auritus L., yellow perch Perca flavescens Mitchell, black crappie Pomoxis nigromaculatus Lesueur, largemouth bass Micropterus salmoides Lacepède; Menhinick 1991) that apparently had been carried downstream in the floodwaters. We rarely observed floating dead fish below New Bern, and the few that were found were freshwater species.

Paerl et al. erred in their treatment of postFran fish kills. In Fig. 1 of Paerl et al., fish kills during September 1996 are shown by 4 evenly spaced stars indicating that the kills extended from $0 \mathrm{~km}$ to the $40 \mathrm{~km}$ mark. However, the NC DWQ fish kill database lists no fish kills downstream from the City of New Bern-that is, no fish kills that actually occurred in the estuary. The NC State database contained 2 major fish kills (not 4, as listed by Paerl et al.) on the Neuse River following the September 1996 hurricane. One of the kills ranged from Streets Ferry down to New Bern, and the second occurred even farther upstream, from Goldsboro down to Kinston. Thus, both of the fish kills in the State database actually occurred in freshwater segments of the Neuse. There is no indication in the State records of a source for Paerl et al.'s estuarine fish kills. 


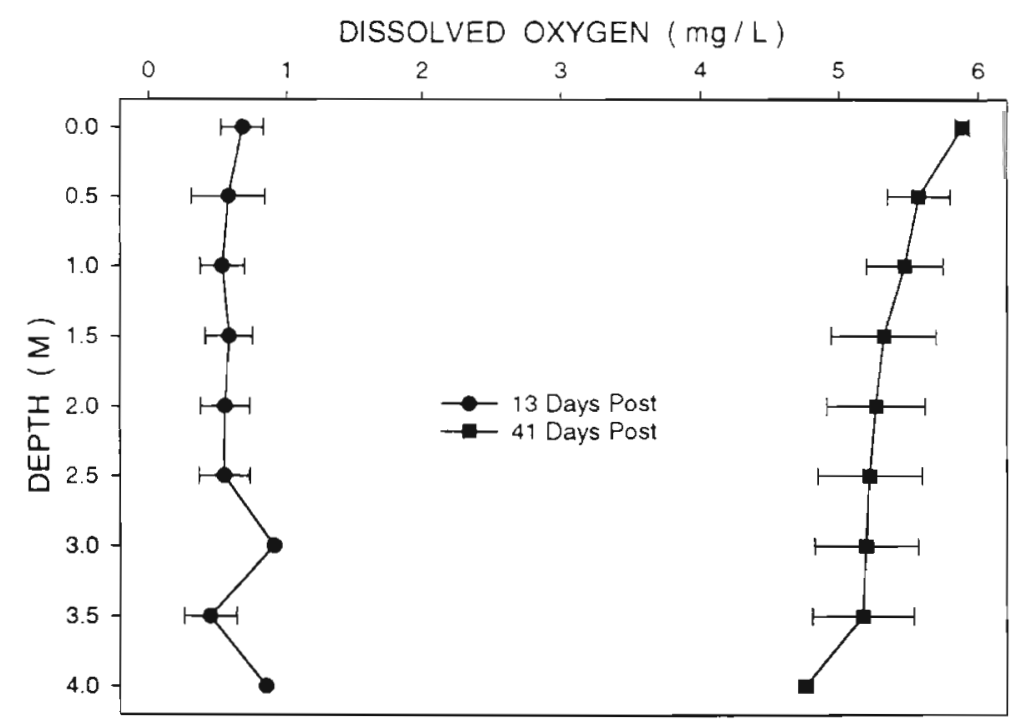

Fig. 5. Depth profiles (mean $\pm \mathrm{SE}$ ) of DO concentrations in the freshwater Neuse River from Kinston downstream to Cox Landing, where a major fish kill was recorded during Week 2 of September 1996 following Hurricane Fran ( $\mathrm{n}=8$, including 4 stations where dead fish were found, and 4 additional downstream stations in the freshwater Neuse). This fish kill was related to anoxia that occurred throughout the water column in a stream segment of length greater than $30 \mathrm{~km}$; thus, refuge areas with adequate DO were not available. DO conditions following recovery (41 d post-hurricane) are presented for comparison

Paerl et al. failed to cite any literature in support of their contention that bottom-water hypoxia and anoxia cause large kills of estuarine, surface-dwelling finfish. Instead, they cited Winn \& Knott (1992), which was a study of how hypoxia affected caged amphipods and clams (northern quahog Mercenaria mercenaria Linne). That paper's conclusion noted severe impacts of hypoxia on amphipods, but also demonstrated strong resistance to hypoxia in the clams. Paerl et al. additionally cited Van Dolah \& Anderson (1991), who provided a detailed description of hypoxia throughout the water column in rivers near Charleston Harbor following Hurricane Hugo. The paper is of high caliber, but no fish kill or hypoxia tolerance data are contained in it - there is only a 1 -sentence mention, in the introduction, of public anecdotes of fish kills following the hurricane.

Lack of statistical evidence. Paerl et al. stated that 'Close scrutiny of the spatial and temporal relationships between hydrology and nutrient (specifically, N) and OM [organic matter] loading in the Neuse River basin over a 3 yr period (1994-1996) reveals a complex but predictable interplay of the timing, magnitude, and delivery of inorganic and organic nutrients, translation into primary production, $\mathrm{O}_{2}$ consumption, hypoxia/ anoxia, and resultant fish and shellfish mortality' (p 24). However, Paerl et al. failed to provide any sta- tistical data to support this statement. The paper contains no predictive regression equations, and no significant correlations among these variables. Instead, the statement was offered that 'The sequence of events linking pulses of $N$ loading to phytoplankton blooms, hypoxia, and fish kills in summer 1995 occurred over weeks to several months.' (p 23). Thus, sound scientific basis was lacking for 'predicting' massive kills of surface-dwelling fishes, as Paerl contended.

Omission of reference to a large body of published data on Neuse fish kills. For some years Paerl et al. have been aware of peer-reviewed, published international science literature relating certain fish kills in the Neuse Estuary to causative factors other than low DO (e.g. Burkholder et al. 1992, 1995, Glasgow et al. 1995, Burkholder \& Glasgow 1997. Burkholder 1998). One major causative agent implicated in the 1995 kills, of particular relevance to the Paerl et al. paper, is the ichthyotoxic dinoflagellate Pfiesteria piscicida Steidinger \& Burkholder. A second, toxic Pfiesteria-like species also has been found in the Neuse Estuary (Burkholder \& Glasgow 1997; note that this organism is not 'Cryptoperidiniopsis' gen. nov. [K. Steidinger, Florida Dept. of Environmental Protection] which has been tested in bioassays as incapable of causing disease or death in fish). The 2 toxic species known thus far comprise the toxic Pfiesteria complex (TPC). TPC species exhibit strong chemosensory attraction to live fish and their fresh tissues (Burkholder \& Glasgow 1997. Glasgow et al. 1998). Multiple laboratories have cross-corroborated that, like certain other toxic dinoflagellates (Burkholder 1998), Pfiesteria can cause fish death and fish disease (Burkholder et al. 1992, 1995, Lewitus et al. 1995, Noga et al. 1996).

Causality of fish death by microbial pathogens or other factors can be inferred, but generally cannot be proven conclusively in a field setting. In our publications, we additionally have attempted to honor, where possible, common implication of low DO in NC DWQ's fish kill summaries. This was done despite having been informed by NC DWQ field personnel that these kills frequently were sampled after fish had been dead for hours to days, and that, on some occasions when fish death was attributed to low oxygen, DO meters were not available so that actual DO data were not taken. Within the affected sites (sometimes large expanses covering 10 to $40 \mathrm{~km}^{2}$ ), we have excluded the TPC from consideration as the primary causative agent if 
more than the lower third of the water column was anoxic/hypoxic over widespread areas (Burkholder \& Glasgow 1997), even though much of the upper water column would have been available to provide oxygenreplete habitat. Thus, we have biased our conclusions in favor of, rather than against, low DO as the primary factor. We additionally have ruled out the TPC if other causative factor(s) can be discerned (Burkholder \& Glasgow 1997)

Fish kills related to the TPC occurred in both 1995 and 1996 (data not available for 1994 because a biohazard III facility was not available to verify toxicity; laboratory records at the Department of Environmental Health Safety of North Carolina State University). We documented one fish kill linked to the TPC in 1996 prior to Hurricane Fran (Burkholder \& Glasgow 1997). The kill involved ca 4000 surface-schooling Atlantic menhaden that died with open blcoding lesions over 2 to $3 \mathrm{~d}$, depending upon the location. Hypoxia affected only the lower $0.5 \mathrm{~m}$ of the $3.5 \mathrm{~m}$ water column in the area where the kill occurred, and there was no evidence of an inversion of low-oxygen water to the surface. This kill, also documented by volunteer citizen sampling and photographs, was not sampled by NC $D W Q ;$ it was described in the published literature (Burkholder \& Glasgow 1997), but was not mentioned by Paerl et al.

More troubling relative to omissions in the Paerl et al. paper is the existence of peer-reviewed, published information on the most massive estuarine fish kill of all 3 years. In that kill, most fish died from 20 September through 25 October 1995. Because of funding limitations, sampling by NC DEHNR personnel generally was limited to 2 dates during the kill, and they did not attempt to extrapolate their data across sampling intervals to estimate dying fish that were missed in their observations. Thus, their estimate of more than 2 million dead Atlantic menhaden was considerably lower than our estimate of ca 15 million fish, which was based on sampling at 3 to $4 \mathrm{~d}$ intervals during most of the $5 \mathrm{wk}$ period in which fish were dying. We also monitored dissolved oxygen and quantified the abundance of Pfiesteria piscicida zoospores. As indicated, about $90 \%$ of the fish affected were Atlantic menhaden, with dead spot Leiostomus xanthuris Lacepede, Atlantic croaker Micropogonias undulatus L., and American eel Anguilla rostrata Lesueur also observed. Periodic intense storm events over the previous spring-early summer had led to unusually low surface salinities; in fact, much of the estuary was at a 4 -year low for that season (Burkholder et al. 1996), delaying the up-estuary migration of juvenile menhaden from the sound. For 1 wk in late June, many areas of the estuary were affected by hypoxia in the lower half of the water column. Storm events with high wind allevi- ated the hypoxia; for 2 wk in early July, there was no hypoxia or hypoxia only in the lower third of the water column. During a 2 wk period in mid-July through early August, many areas of the estuary were affected by hypoxia/anoxia in about half to two-thirds of the water column. This oxygen deficit was linked to an Atlantic menhaden kill (Burkholder \& Glasgow 1997). Additional schools of juvenile Atlantic menhaden moved up-estuary from the sound after storms and cooler temperatures alleviated the oxygen sags. There was no, or only bottom-water, hypoxia/anoxia from the second week of August through September in most of the large-expanse kill area $\left(40 \mathrm{~km}^{2}\right.$; Burkholder et al. 1996, NC DWQ state records).

About 2 wk prior to the kill, a small percentage of the Atlantic menhaden in the affected area manifested open, bleeding lesions. Such chronic lesions have been associated with opportunistic fungi (Noga 1993); more recently, they have been correlated with oiner potential causative agents such as an invasive fungus (Aphanomyces cf. invadens; Lilley et al. 1997, Blazer et al. 1998). Lesions with similar appearance also can be caused by certain toxic chemicals (Noga 1993). Moreover, the toxins of Pfiesteria. piscicida (as well as the second toxic Pfiesteria-like species) have been demonstrated to destroy fish epidermis, cause and contribute to lesions, and depress the fish immune system (Noga et al. 1996, Burkholder \& Glasgow 1997). Thus, toxin(s) from the TPC can compromise epidermal tissues rendering them susceptible to fungal attack. There is evidence in support of a role of the TPC as causative agents of chronic lesions in menhaden under field conditions, considering the chronology of events. Fish that are exposed to sublethal levels of TPC species' toxins become narcotized and lethargic $i_{i}$ they show poor fright response, disorientation, and loss of balance and, thus, would be expected to remain in the general area (Burkholder et al. 1995. Burkholder \& Glasgow 1997) In a pattern typical of Pfiesteria-related menhaden kills, the incidence of lesions increased from 5-7\% across the tested area $2 \mathrm{wk}$ before the late summer 1995 kill to $15-19 \% 1 \mathrm{wk}$ later. Within $2 \mathrm{~d}$ after the kill began, toxic Pfiesteria piscicida zoospores were at $\mathrm{ca} 1200$ cells $\mathrm{ml}^{-1}$ in the epicenter of the kill zone (later verified using a molecular probe for this species which was developed by Dr. P. Rublee, University of North Carolina, Greensboro, with our laboratory). The percentage of fish with large open lesions (up to 1 to $2 \mathrm{~cm}$ in diameter; average fish length $25 \pm 7 \mathrm{~cm}$ ) had sharply increased to nearly $80 \%$. At 4 d into the kill, while a toxic population of $P$. piscicida remained active (verified by bioassays with test fish), nearly $95 \%$ of the menhaden had such lesions.

When the late summer 1995 kill began, we sampled dying/dead fish with bleeding lesions in the oxygen- 
replete upper third of the water column (at dawn; state-certified laboratory, Burkholder et al. 1996). We further documented that the water column throughout the entire area had $5 \mathrm{mg} \mathrm{DO} \mathrm{l}^{-1}$ or more, or hypoxia only in the lower third of the water column. Over this large expanse of area, the stench of rotting fish prompted a groundswell of public outcry as local citizens demanded that state officials address the problem (illustrated by news articles such as Brodeur 1995). On 4 October, fully 2 wk after the fish kill began and with ca 7 million rotting dead fish in the water or along the shores (observed directly by J.M.B. \& H.B.G., who assisted in the counts), hypoxia affected about half of the water column in 2 of 6 sites monitored, and a third site had low oxygen throughout the water column. The remaining 3 sites, where many of the fish died with bleeding lesions, had no hypoxia or hypoxia only in the lower third of the water column (Burkholder et al. 1996).

During the massive Pfiesteria-related fish kill in 1995, P. piscicida (400 to 2000 toxic zoospores $\mathrm{ml}^{-1}$; verified using our molecular probe) was at potentially lethal densities (Burkholder \& Glasgow 1997). Since pesticides and other factors also can cause lesions and kill fish (although such factors were not known to have been involved in the death of the surface-schooling Atlantic menhaden), we were careful to verify insofar as possible that active, toxic populations of $P$. piscicida were present. Toxicity of this dinoflagellate was confirmed through experimental bioassays of field samples with test fish, in this major fish kill as well as in other kills where it was implicated (Burkholder et al. 1995, Burkholder \& Glasgow 1997; note that such bioassays with Pfiesteria also have been published by Noga et al. 1993 and Lewitus et al. 1995). Species identification was confirmed from scanning electron microscopy of suture-swollen cells (procedure modified from Truby 1997), after obtaining sufficient cells from the fish bioassays for this technique

The first author of the Paerl et al. paper was in attendance at several videotaped scientific forums in which, as well as in the peer-reviewed published literature, it was demonstrated that $95 \%$ of these fish died with the previously mentioned bleeding lesions while Pfiesteria zoospores (see below) were swarming in the oxygenrich surface waters (Burkholder \& Glasgow 1997, Burkholder 1998; also verified by A. Hodge, NC DWQ, Washington, NC). TPC species are similar to certain other harmful algae and dinoflagellates in their ability to produce toxins that can cause fish death (Burkholder \& Glasgow 1997; corroborated by Noga et al. 1993, Lewitus et al. 1995); and, like other of these harmful species, the toxins of TPC species have not yet been well-characterized (Burkholder 1998). Toxins that have been isolated and semi-purified from $P$. piscicida have been tested as highly lethal to finfish (Fairey et al. 1998). The fact that potent ichthyotoxin from $P$. piscicida had been verified also was conveyed in 2 science presentations at a public forum (National Institutes of Environment Health Sciences, Research Triangle Park, NC, August 1997), with the first author of the Paerl et al. paper in attendance.

It is critical that major factors which historically have been implicated as causative agents of fish mortality in the Neuse Estuary be considered when attempting to make predictive statements. The first and second authors of the Paerl et al. paper were aware of the large body of peer-reviewed publications on Pfiesteria and some of the same kills of surface-schooling menhaden that they attributed solely to bottom-water low DO. Our previous publications point out that factors other than Pfiesteria likely were the primary cause of some kills. For example, while certain fish kills were attributed to Pfiesteria, the 1996 post-Hurricane Fran kills in freshwater segments, from which fish were transported to the oligohaline estuary, were related to hypoxia/anoxia throughout the water column (Burkholder \& Glasgow 1997). We further note that the freshwater post-Fran kills occurred where the entire water column was anoxic (Fig. 5). As previously stated, there were no estuarine fish kills listed in the NC DWQ database. Nor did we document fish kills in the mesohaline estuary during extensive post-Hurricane sampling. All fish kills that we linked to the TPC during 1995 and 1996 were supported by both field sampling and verifi-cation of active toxic populations of this dinoflagellate from experimental fish bioassays with field water samples.

Paerl et al. indicated that low DO was the causative factor for all of the 1995 fish kills that they described. In so doing, they also failed to mention the following widely disseminated information which is pertinent to the late summer 1995 fish kills. On 13 October 1995, during what became a highly publicized event, the director of the North Carolina Division of Marine Fisheries (NC DMF) ordered a ca $40 \mathrm{~km}^{2}$ segment of the Neuse Estuary closed to all fishing activity, specifically because a toxic Pfiesteria outbreak had been verified and was linked to the massive kill in which millions of fish died with open, bleeding lesions (NC DMF 1995 , Diaby 1996). The toxic outbreak, and negative publicity stemming from it, led to its formal recognition as a threat to the economy of the commercial fishing industry in unaffected North Carolina estuaries (Diaby 1996).

Data are also available in support of this dinoflagellate as a causative agent of major fish kills in other waters. During 1997, kills of ca $3 \times 10^{4}$ Atlantic menhaden in Chesapeake Bay tributaries led to increased 
national recognition of the TPC's role in both fish kills and human health impacts (Maryland Department of Health \& Mental Hygiene 1997, Burkholder 1998, Grattan et al. 1998). The widely publicized kills were covered in North Carolina, and in national and international news media. The kills were linked to active, toxic populations of Pfiesteria piscicida (with toxic activity confirmed in experimental bioassays with fish). The associated environmental conditions were similar to those in the mesohaline Neuse (i.e. calm, shallow, nutrient-enriched brackish waters with abundant phytoplankton); and the kills clearly were unrelated to low DO (Tidewater Ecosystem Assessment Division 1998). Moreover, serious impacts of toxic Pfiesteria on mam- malian as well as fish health have been documented, in both laboratory and field settings (Glasgow et al. 1995, Levin et al. 1997, Maryland Department of Health \& Mental Hygiene 1997, Grattan ct al, 1998).

Yet, despite all of this evidence in support of the TPC as major causative agents of fish kills in the Neuse, in other waters of North Carolina, and in waters of other states, Paerl et al. failed to mention the existence of these organisms. Moreover, they failed to point out that the fish kills that they claimed to have been 'caused' by bottom-water hypoxia/anoxia involved surface-schooling fish that died with bleeding lesions-or that certain of these kills previously had been linked to toxic Pfiesteria/Pfiesteria-like dinoflagellates with supporting fish bioassays, as described in multiple peer-reviewed publications of which Paerl et al. were aware.

Implications. The hypothesis 'Nutrient loading can lead to phytoplankton blooms, oxygen sags, and fish kills' has strong support in previously published research (e.g. Baden et al. 1990, Vitusek et al. 1997). We regard hypoxia/anoxia as an important factor in estuarine fish health (Pihl et al. 1991), fish survival from predation (Breitburg et al. 1997), and fish kills (Breitburg 1992) under some circumstances. Excessive nutrient loading to estuaries (e.g. Jaworski 1981, Howarth et al. 1991, Magnien et al. 1992) has been strongly correlated with development of nuisance or noxious phytoplankton blooms (Smayda 1989, Gallegos et al. 1992, Dennison et al. 1993, Mallin et al. 1993), and respiration of such blooms at night can significantly depress oxygen, leading to fish kills (reviewed in Paerl 1988, Diaz et al. 1992).

But even the best of hypotheses should not be invoked as fact in published work without supporting data. Water quality degradation has occurred from cultural eutrophication in many estuaries, and it is a fact that fish can die from low-oxygen stress. It is also a fact that the dinoflagellate Pfiesteria piscicida and close relatives in the TPC, like various other dinoflagellate species, can promote fish disease and death (Burk- holder et al. 1992, 1995, Noga et al. 1993, 1996, Lewitus et al. 1995, Burkholder \& Glasgow 1997). Although either variable alone-hypoxia/anoxia or the TPC-has been demonstrated to cause fish death, it is reasonable to expect that at sublethal/chronic levels, these as well as other stressors would interact to impair fish health (Burkholder et al. 1995, Blazer et al. 1998) and that their roles as primary versus secondary factors could interchange depending upon the specific conditions. Such interactions between low-oxygen stress and the TPC in impairing fish health, as well as interactions among these factors, other adverse environmental conditions, and other toxins and microbial pathogens, merit examination. But dissolved oxygen alone is not an overall 'integrator' of the factors that can effect fish kills and epizootics in estuaries. Nor is it a sufficient index of eutrophication impacts on fish, since various fish pathogens which are not known to be linked to DO deficits thrive in eutrophic estuaries (Noga 1993, Burkholder \& Glasgow 1997).

We recommend caution in attempts to determine the primary causative factor(s) of estuarine fish kills. Causality would be expected to depend, in part, on the behavior of the species involved. For benthic-dwelling finfish and shellfish, accumulation of toxic substances such as pesticides or heavy metals (Hackney et al. 1998), or burial from a sudden major disturbance, could be lethal. For surface-schooling fish, ichthyotoxic Pfiesteria/Pfiesteria-like species may be suspected based on the presence of potentially lethal levels of zoospores $\left(\geq 250 \mathrm{ml}^{-1}\right)$ in areas where fish are distressed or dying, especially in poorly flushed brackish areas during warm seasons where large numbers of Atlantic menhaden are lethargic with open, bleeding lesions (Burkholder \& Glasgow 1997). However, the presence of appropriate cell densities alone is not enough to invoke causality because TPC dinoflagellates can exist as nontoxic stages and strains. TPC species should be implicated as the primary causative agent(s), in the absence of other known lethal factors within the kill zone, only after an active, toxic population is confirmed in water samples from the in-progress kill. Until an assay is available for rapid toxin detection in field water samples, bioassays with test fish should be used as supporting experimental evidence (Burkholder \& Glasgow 1997).

Hypoxia/anoxia should be invoked with caution in fish kills, on the basis of supporting data that demonstrate low oxygen conditions prior to (if possible) as well as during the period when-and where-fish are dying. Bottom-water hypoxia would be expected to be lethal to benthic finfish and shellfish, especially sessile forms that could not move to refuge areas with adequate oxygen. To interpret the importance of low oxygen in the upper water column to surface-schooling 
fish, the presence, versus absence, of adjacent oxygenreplete refuge areas should be documented. The practice of invoking low dissolved oxygen as a 'best guess' when an area is examined after decomposing fish have been dead for hours to days in warm waters, or when an area some distance (e.g. several kilometers) from the kill zone has low oxygen but the area where fish are dead/dying does not, should be avoided. Use of DO measurements from fixed-station buoys can be helpful, with the following caveats: (1) the buoys should be within the kill zone, (2) inversions of hypoxic bottom water to the surface should be documented in the area where fish were affected, and (3) DO probes should be calibrated with sufficient frequency to prevent spurious (erroneously low) data due to fouling of probe membranes with fine sediments and microbial overgrowth. This problem would need to be considered especially during warm seasons in turbid, highly productive estuaries such as the Albemarle-Pamlico.

Overall, strengthened strategies to improve management of coastal fisheries in response to fish kills and epizootics will only occur through the contribution of strong scientific field data backed by experimental testing; conclusions that do not prematurely invoke prediction or otherwise extend beyond the data; and balanced interpretations formed after careful review of the available literature and earnest attempts to consider alternatives. This approach also will help to foster greater appreciation, in management decisions to protect fish health, for the multiple stresses that must be confronted by estuarine fish populations.

Acknowledgements. Funding support for our study of the Neuse River and Estuary was provided by the U.S. Marine Air Station-Cherry Point, the National Science Foundation (grant OCE 94-3920), the North Carolina Agricultural Research Foundation (project 93-0042), the North Carolina Agricultural Research Service (project 06034), the NCSU College of Agriculture \& Life Sciences, and the NCSU Department of Botany. We thank the Division of Water Quality of NC DENR fformerly within the Division of Environmental Management of the North Carolina Department of Environment, Health and Natural Resources) for updates on the state's official fish kill database. We are grateful to D. Briley, N. DeamerMelia, R. Dove, E. Hannon, A. Hodge, M. Larsen, K. Lynch, J. Manning, and C. Willis for assistance in field sampling. Four anonymous reviewers kindly critiqued the writing, as well as the science, contained in the manuscript.

\section{LITERATURE CITED}

Anonymous (1997) Fran squeezes the life out of NC waters. Environ Health Perspect 105:23-25

Baden SP, Loo O Pihl, L Rosenberg R (1990). Effects of eutrophication on benthic communities including fish: Swedish west coast. Ambio 19:113-122

Bales JD, Oblinger S, Childress CJ (1996) Aftermath of Hurricane Fran in North Carolina: preliminary data on flooding and water quality. Open File Report 96-499. USGS, Raleigh, NC

Blazer VS, Densmore CL, May E, Vogelbein W (1998) Lesions observed in menhaden collected during fish kills and during other collections in tributaries of the Chesapeake Bay. In: Proc 3rd Int Symp Aquatic Animal Health. APC Press, Baltimore, MD, p 108

Breitburg DL (1992) Episodic hypoxia in Chesapeake Bay: ineracting effects of recruitment, behavior, and physical disturbance. Ecol Monogr 62:525-546

Breitburg DL (1994) Behavioral response of fish larvae to low dissolved oxygen concentrations in a stratified water column. Mar Biol 120:615-625

Breitburg DL, Loher T, Pacey CA, Gerstein A (1997) Varying effects of low dissolved oxygen on trophic interactions in an estuarine food web. Ecol Monogr 67:489-507

Brodeur N (1995) Like a scene from Jaws. News \& Observer, 4 October, Raleigh, NC

Burkholder JM (1998) Implications of harmful marine microalgae and heterotrophic dinoflagellates in management of sustainable fisheries. Ecol Appl (Suppl) 8:S37-\$62

Burkholder JM, Glasgow HB Jr (1997) Pfiesteria piscicida and other Pfiesteria-like dinoflagellates; behavior, impacts, and environmental controls. Limnol Oceanogr 42 : $1052-1075$

Burkholder JM, Glasgow HB Jr, Hobbs CW (1995) Fish kills linked to a toxic ambush-predator dinoflagellate: distribution and environmental conditions. Mar Ecol Prog Ser 124: $43-61$

Burkholder JM, Noga EJ, Hobbs CW, Glasgow HB Jr, Smith SA (1992) New 'phantom' dinoflagellate is the causative agent of major estuarine fish kills. Nature 358:407-410; Nature 359:760

Burkholder JM, Glasgow H Jr, Fensin E (1996) Neuse Estuary biomonitoring study. Final Report to the U.S. Marine Air Station, Cherry Point, NC. North Carolina State University, Raleigh

Dennison WC, Orth RJ, Moore KA, Stevenson JC, Carter V, Kollar S, Bergstrom PW, Batiuk RA (1993) Assessing water quality with submerged aquatic vegetation. BioScience $43: 86-94$

Diaby S (1996) Economic impact of the Neuse River closure on commercial fishing. North Carolina Division of Marine Fisheries, Morehead City, NC

Diaz RJ, Neubauer RJ, Schaffner LC, Pihl L, Baden SP (1992) Continuous monitoring of dissolved oxygen in an estuary experiencing periodic hypoxia and the effect of hypoxia on macrobenthos and fish. In: Vollenveider RA, Marchetti R, Viviani R (eds) Marine coastal eutrophication: the response of marine transitional systems to human impacts - problems and perspectives for restoration. Elsevier, Amsterdam, p 1055-1068

Fairey ER, Edmunds JS, Deamer-Melia NJ, Glasgow $\mathrm{H} \mathrm{Jr}$, Johnson FM, Moeller PR, Burkholder JM, Ramsdell JS (1998) Reporter gene assay for fish-killing activity produced by Pfiesteria piscicida. Proc Annu Meet Int Gordon Conf (Feb. 1998, Ventura, CA)

Friedland KD, Ahrenholz DW, Guthrie JF (1989) Influence of plankton on distribution patterns of the filter-feeder Brevoortia tyrannus (Pisces: Clupeidae). Mar Ecol Prog Ser $54: 1-11$

Gallegos CL, Jordan TE, Correll DL (1992) Event-scale response of phytoplankton to watershed inputs in a subestuary: timing, magnitude, and location of blooms. Limnol Oceanogr 37:813-828

Glasgow HB Jr, Burkholder JM, Schmechel DE, Tester PA, Rublee PA (1995) Insidious effects of a toxic dinoflagellate 
on fish survival and human health. $J$ Toxicol Environ Health 46:101-122

Glasgow HB Jr, Lewitus AJ, Burkholder JM (1998) Feeding behavior of the ichthyotoxic estuarine dinoflagellate, Pfiesteria piscicida, on amino acids, algal prey, and fish vs. mammalian erythrocytes. In: Reguera B, Blanco J, Fernandez ML, Wyatt $T$ (eds) Harmful microalgae. Proc 8 th Int Conf Harmful Algal Blooms, Xunta de Galicia and UNESCO, Paris, p 394-397

Grattan LM, Oldach D, Perl TM, Lowitt MH, Matuszak DL, Dickson C, Parrot C, Shoemaker RC, Wasserman MP, Hebel JR, Charache P, Morris JG (1998) Problems in learning and memory occur in persons with environmental exposure to waterways containing toxin-producing Pfiesteria or Pfiesteria-like dinoflagellates. Lancet 352:532-539

Hackney CT, Grimley J, Posey M, Alphin T, Hyland J (1998) Sediment contamination in North Carolina's estuaries. Publ no. 198 of the Center for Marine Science Research. University of North Carolina, Wilmington

Hettler WF Jr, Barker DL (1993) Distribution and abundance of larval fishes at two North Carolina inlets. Estuar Coast Shelf Sci 37:161-179

Howarth RW (1991) Comparative responses of aquatic ecosystems to toxic chemical stress. In: Cole JJ, Findlay S, Lovett $\mathrm{G}$ (eds) Comparative analysis of ecosystems: patterns, mechanisms, and theories. Springer-Verlag, New York, p 161-195

Jaworski, NA (1981) Sources of nutrients and the scale of eutrophication problems in estuaries. In: Nielson BJ, Cronini LE (eds) Estuaries and nutrients. Humana Press, Clifton, $N J$

Levin ED, Schmechel DE, Burkholder JM, Glasgow HB Jr Deamer-Melia N, Moser VC, Harry GJ (1997) Persistent learning deficits in rats after exposure to Pfiesteria piscicida. Environ Health Perspect 105:1320-1325

Lewitus AJ, Jesien RV, Kana TM, Burkholder JM, Glasgow HB Jr, May E (1995) Discovery of the 'phantom' dinoflagellate in Chesapeake Bay. Estuaries 18:373-378

Lilley JH, Hart D, Richards RH, Roberts RJ, Cerenius L, Soderhall K (1997) Pan-Asian spread of single fungal clone results in large-scale fish kills. Vet Rec 140:653-654

Lowe JA, Farrow DRG, Pait AS, Arenstam SJ, Lavan EF (1991) Fish kills in coastal waters 1980-1989. National Oceanic \& Atmospheric Administration-Strategic Environmental Assessments Division, Washington, DC

Magnien RE, Summers RM. Sellner KG (1992) External nutrient sources, internal nutrient pools, and phytoplankton production in Chesapeake Bay. Estuaries 15:497-516

Mallin MA, Paerl HP, Rudek J, Bates PW (1993) Regulation of estuarine primary production by watershed rainfall and river flow. Mar Ecol Prog Ser 93:199-203

Mallin MA, Posey MH, Shank GC, Mclver MR, Ensign SH, Alphin TD (1999) Hurricane effects on water quality and benthos in the Cape Fear watershed: natural and anthropogenic impacts. Ecol Appl 9:350-362

Manooch CS III (1988) Fisherman's guide-fishes of the southeastern United States. North Carolina Museum of Natural History, Raleigh

Maryland Department of Health \& Mental Hygiene (1997) State records. Baltimore, MD

Menhinick EF (1991) The freshwater fishes of North Carolina North Carolina Wildlife Resources Commission, Raleigh

Migdalski EC, Fichter GS (1989) The fresh and salt water fishes of the world. Greenwich House, New York

Noga EJ (1993) Fungal diseases of marine and estuarine fishes. In: Couch JA, Fournie JW (eds) Pathobiology of marine and estuarine organisms. CRC Press, Boca Raton, p 85-100

Noga EJ, Smith SA, Burkholder JM, Hobbs CW, Bullis RA (1993) A new ichthyotoxic dinoflagellate: cause of acute mortality in aquarium fishes. Vet Rec 133:96-97

Noga EJ, Khoo L, Stevens JB, Fan Z, Burkholder JM (1996) Novel toxic dinoflagellate causes epidemic disease in estuarine fish. Mar Pollut Bull 32:219-224

NC DEHNR (North Carolina Department of Environment, Health \& Natural Resources) (1996a) Classifications and water quality standards applicable to surface waters of North Carolina. North Carolina Administrative Code Sections 15A NCAC2B.0100 and 15A NCAC2B.0200. North Carolina Environmental Management Commission, Raleigh

NC DEHNR (1996b) Weather-related situations at animal facilities/publicly owned treatment facilities affected by Hurricane Fran. Draft report. NC DEHNR, Raleigh, NC

NC DMF (North Carolina Division of Marine Fisheries) (1995) Minutes of North Carolina Division of Marine Fisheries emergency meeting, New Bern, NC, October 13, 1995. NC DMF, Morehead City, NC

Paerl HW (1988) Nuisance phytoplankton blooms in coasial, estuarine and inland waters. Limnol Oceanogr 33:823-847

Paerl HW, Mallin MA, Donahue CA, Go M, Peierls BL (1995) Nitrogen loading sources and eutrophication of the Neuse River Estuary, North Carolina: direct and indirect roles of atmospheric deposition. Report no. 291. UNC Water Resources Research Institute, Raleigh

Paerl HW, Pinckney JL, Fear JM, Peierls BL (1998) Ecosystem responses to internal and watershed organic matter loading: consequences for hypoxia in the eutrophying Neuse River Estuary, North Carolina, USA. Mar Ecol Prog Ser $166: 17-25$

Pihl L, Baden SP, Diaz RJ (1991) Effects of periodic hypoxia on distribution of demersal fish and crustaceans. Mar Biol 108:340-360

Renaud M (1986) Hypoxia in Louisiana coastal waters during 1983: implications for fisheries. Fish Bull 84:19-26

Smayda TJ (1989) Primary production and the global epidemic of phytoplankton blooms in the sea: a linkage? In Cosper EM, Bricelj VM, Carpenter EJ (eds) Novel phytoplankton blooms: causes and impacts of recurrent brown tides and other unusual blooms. Coast Estuar Stud 35 : $450-481$

Tidewater Ecosystem Assessment Division (1998) Water quality, habitat and biological conditions of river systems affected by Pfiesteria or Pfiesteria-like organisms on the lower eastern shore of Maryland: 1997 summary. Resource Assessment Service, Maryland Department of Natural Resources, Annapolis, MD

Truby EW (1997) Preparation of single-celled marine dinoflagellates for electron microscopy. Microsc Res Tech 36: $337-340$

Van Dolah RF, Anderson GS (1991) Effects of Hurricane Hugo on salinity and dissolved oxygen conditions in the Charleston Harbor estuary. J Coastal Res (SI) 8:83-94

Vaughn DS (1991) Menhaden: the resource, the industry, and a management history. Mar Fish Rev (Spec Issue) 53:1-2

Vitusek PM, Aber JD, Howarth RW, Likens GE, Matson PA, Schindler DW, Schlesinger WH, Tilman DG (1997) Human alterations of the global nitrogen cycle: sources and consequences. Ecol Appl 7:737-750

Winn RN, Knott DM (1992) An evaluation of the survival of experimental populations exposed to hypoxia in the Savannah River Estuary. Mar Ecol Prog Ser 88:161-179 